\title{
Social Capital: A Source of Sustained Competitive Advantage for Consumer Co-operatives
}

\author{
Terhi Tuominen ${ }^{1}$, Pasi Tuominen ${ }^{1}$, Heidi Tuominen ${ }^{1} \&$ Iiro Jussila $^{1}$ \\ ${ }^{1}$ Department of Management and International Business, School of Business, Lappeenranta University of \\ Technology, Finland \\ Correspondence: Terhi Tuominen, Department of Management and International Business, School of Business, \\ Lappeenranta University of Technology, P.O. Box 20, FIN-58351, Finland. E-mail: terhi.tuominen@lut.fi
}

Received: August 14, 2013

Accepted: September 5, 2013

Online Published: November 22, 2013

doi: 10.5539/ibr.v6n12p60

URL: http://dx.doi.org/10.5539/ibr.v6n12p60

\begin{abstract}
Competitive advantages of consumer co-operatives have received increasing scholarly attention during the recent years. In the extant literature, co-operative social capital (derived from the co-operative values, purpose, and principles) has been identified as a source of competitive advantage for co-operatives. However, the literature lacks empirical evidence concerning how the sources of social capital are developed and utilized in consumer co-operation and what strategic benefits consumer co-operatives achieve by utilizing and developing different sources of social capital. Our paper is directed toward this end. In our study, we thematically analyze 20 qualitative interviews with executives, managers, and supervisory board chairs of Finnish retail and service organization S Group and its co-operatives. Our findings indicate that there are several sources of social capital for consumer co-operatives (e.g. interacting and sharing a common identity). Further, we consider how these sources of social capital are interrelated to different dimensions of social capital (communal, relational, and cognitive). We also describe the strategic benefits that the different dimensions of social capital create, the most important finding being that social capital may help consumer co-operatives to achieve a sustained competitive advantage by providing resources for managing institutional dependencies and customer-relations.
\end{abstract}

Keywords: co-operation, consumer co-operative, social capital, strategic management, competitive advantage

\section{Introduction}

Competitive advantages of consumer co-operatives have received increasing academic attention during the recent years. Scholars have emphasized the intimate relationship consumer co-operatives are likely to have with their local communities (e.g., Jussila, Tuominen \& Saksa, 2008; Jussila, Kotonen \& Tuominen, 2007; Tuominen, Jussila \& Saksa, 2006; Uski, Jussila \& Saksa, 2007; Zeuli \& Radel, 2005; Zeuli, Freshwater, Markley \& Barkley, 2004; Fulton \& Hammond-Ketilson, 1992), suggesting that this embeddedness stemming from the purpose of consumer co-operation (Tuominen, 2012) provides them competitive advantage over investor-owned firms (IOFs). That is, consumer co-operatives are network-organizations with an extra communication capacity (as users are also the owners) and this kind of an active communication network can be used as a tool for developing efficient and effective business organizations (Normark, 1996). Further, in addition to the linkages between the members and their co-operative, consumer co-operatives are part of the regional networks of their operation areas (Uski, Jussila \& Saksa, 2007), giving them both knowledge of local conditions as well as the power to alter those conditions which then enables to make decisions that take into account the members' welfare (Fulton \& Hammond-Ketilson, 1992) and to utilize the benefits of locality and regionality (Tuominen et al., 2006).

In addition, various co-operative scholars (e.g., Davis \& Burt, 2007; Fulton \& Hammond-Ketilson, 1992; Normark, 1996; Novkovic, 2008; Spear, 2000; Valentinov, 2004) have emphasized how the co-operative social values and principles (e.g., honesty, openness, democracy) increase the development of trustful relationships which give them a competitive advantage over IOFs. For example, Spear (2000) argues that profit distribution constrains in consumer co-operatives are likely to increase trust and that managers are more likely to perform in line with users' preferences since returns to members are a key measure of performance. Spear (2000) refers to this as "social effiency" and puts forward that the associative nature of co-operatives and their strong linkages to the community provide a basis for the utilization of social capital. That is, local stakeholders may look at them more favorably as co-operatives have "genuine interest" in developing the territory in which they are embedded (Jussila et al., 2007). 
Thus, the social side of co-operatives should not been undermined or underestimated in consumer co-operatives. For example, Davis and Burt (2007) argue that "the absence of social values denies co-ops their natural profile, renders them similar to their competitors to the point of not being able to distinguish them and denies them their natural competitive advantage". Valentinov (2004) has even found social capital to be a cost-effective governance mechanism and as one that is linked to the principles of co-operation. The interconnection between social capital and co-operative principles has also been identified in studies of producer co-operatives (Nilsson, Svendsen \& Svendsen, 2012; Svendsen \& Svendsen, 2000) that have provided some insights on how the erosion of social capital negatively effects the co-operatives' and communities' economic growth (Nilsson et al., 2012).

In sum, by so far, consumer co-operative scholars have acknowledged that co-operative purpose, values, principles, and co-operatives' embeddedness with their communities (and concern for their communities) create additional trust and social capital which can be seen as sources of competitive advantage and success. However, although providing some important pieces of information, extant literature is rather fragmented and none of the above listed studies has engaged into empirical investigation concerning (1) How is social capital developed in consumer co-operation? and (2) What strategic benefits do consumer co-operatives achieve by developing and utilizing social capital? In this paper, we define strategic benefits as those which contribute to sustained competitive advantage, referring to implementation of " a value creating strategy not simultaneously being implemented by any current or potential competitors and when these other firms are unable to duplicate the benefits of this strategy" (Barney, 1991).

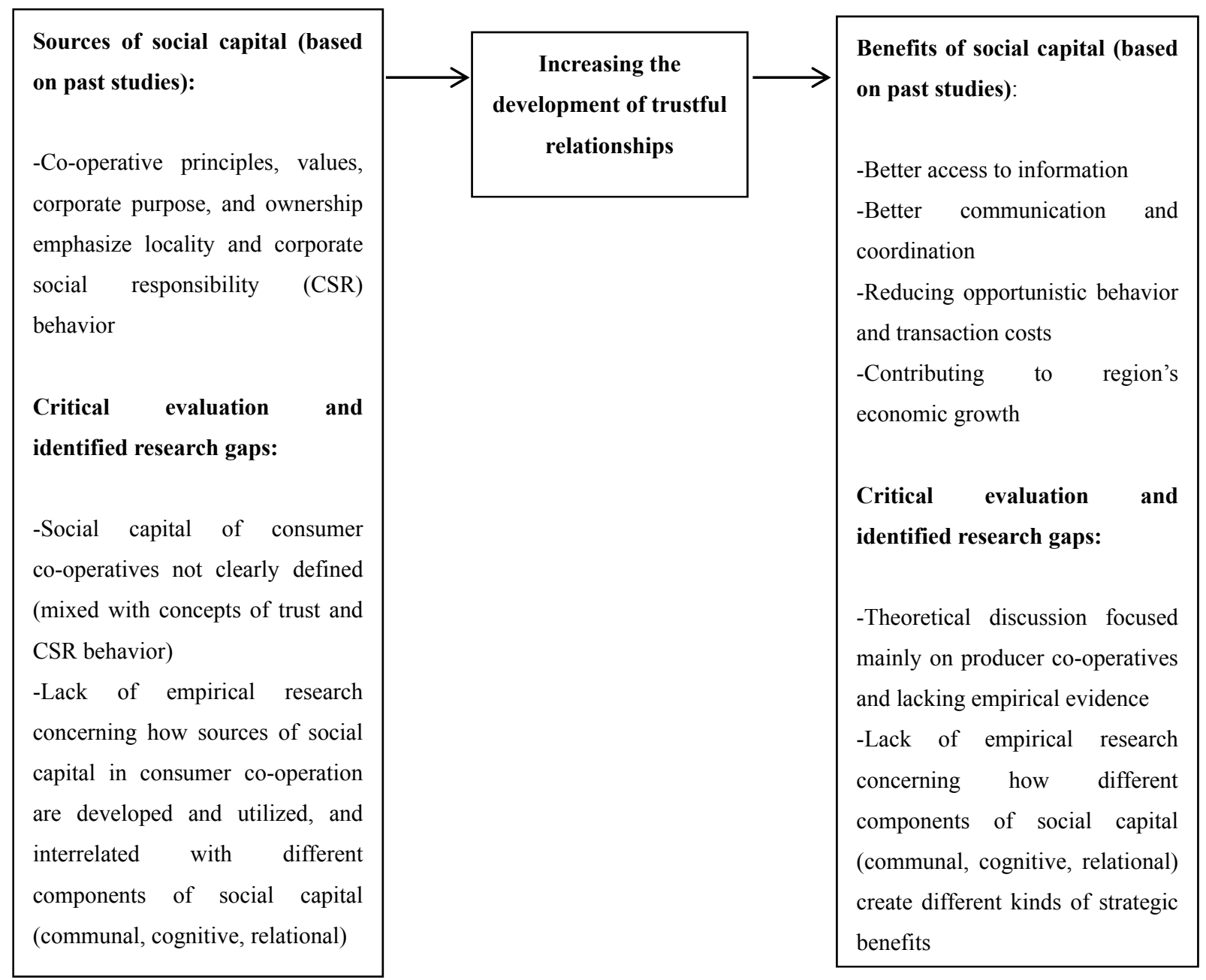

Figure 1. Social capital and co-operatives 
Figure 1 presents the research background and the knowledge gap. To fill the knowledge gap, we use a qualitative case study approach (see Gioia, Corley \& Hamilton, 2012). Our data consists of 20 interviews with executives, managers, and key representatives of a Finnish consumer co-operative group (S Group co-operatives). The texts generated in the interviews are analyzed by using thematic analysis (Braun \& Clarke, 2005; Gioia et al., 2012).

Our paper is organized as follows. First, we review literature on social capital and co-operatives in order to provide some theoretical background to the phenomenon under examination. Then, we introduce our research context, data, and methods. We continue with data analysis and association of ideas based on our data. After summarizing our findings, we discuss the contribution of our study to future research and practice of consumer co-operation.

\section{Social Capital and Co-operatives}

In this section, we will take a brief look at the definition of social capital and the research of social capital in the co-operative context. The latter part will provide the reader with a more detailed description of the body of knowledge that this paper is set to advance.

\subsection{The Dimensions of Social Capital}

Social capital theory focuses on the significance of social relationships and networks that have resource advantages to both individuals and communities (Ibarra, Kilduff \& Tsai, 2005; Nahapiet \& Ghoshal, 1998; Putnam, 1993; Bordieu, 1986). Social capital has been conceptualized in several different ways. Adler and Kwon (2002) differentiate the substance, sources, and effects of social capital, suggesting that social capital is "the goodwill available to individuals or groups. Its source lies in the structure and content of the actor's social relations. Its effects flow from the information, influence, and solidarity it makes available to the actor" (p. 23).

Also, structural hole theory (e.g., Burt, 1997) has been applied in the context of social capital. It defines social capital in terms of "the information and control advantages of being the broker in relations between people otherwise disconnected in social structure" (Burt, 1997, p. 340). The disconnected actors are seen as standing on opposite sides of 'a hole' in some social structure, which manifests an opportunity for an actor to act as a mediatorin the flow of information between people and control the form of projects that associate actors around the hole.

Ibarra et al. (2005) divide social capital into two types: (1) individual (i.e., benefits that accrue from individual network connections) and communal (i.e., connections between actors that enhance public goods to the benefit of the entire network, or collectivity). Research focusing on individuals and social capital has mainly assumed that individuals use network ties instrumentally, pursuing opportunities that benefit themselves (Bourdieu, 1985). That is, they may strive to advance their careers with usage of diverse information and resources, which are captured through connections bridging disconnected clusters (Burt, 1992; 2004). In contrast, research focused on communal social capital has mostly been based on the assumption that connections between actors promote public good to the benefit of the entire network (Putnam, 1993). Thus, strong social capital within and between informal groups in an organization may reduce the occurrence of events that affect all organizational members negatively (Nelson, 1989).

Another way of conceptualizing social capital is put forward by Nahapiet and Ghoshal (1998) who define it as "the sum of the actual and potential resources embedded within, available through, and derived from the network of relationships possessed by an individual or social unit' (p. 243). Further, in their exploration of the role of social capital in the creation of intellectual capital, they suggest that social capital has three dimensions: 1) structural, 2) relational, and 3) cognitive. Structural dimension of social capital refers to "the overall pattern of connections between actors" (p. 244) - that is, who you reach and how you reach them (Burt, 1992). Relational dimension refers to "those assets created and leveraged through relationships" (Nahapiet \& Ghoshal, 1998). The third dimension labeled as cognitive refers to resources that provide shared representations, interpretations, and systems of meaning among different parties (Cicourel, 1973). In addition, several authors (e.g., Woolcock \& Narayan, 2000; Putnam, 1993; 2000) have referred to bridging dimension of social capital (outward looking, encompassing people across diverse social cleavages) and bonding social capital (inward looking, tending to reinforce exclusive identities and homogeneous groups).

In sum, the various definitions of social capital vary, firstly, depending on whether they focus on the substance, the sources, or the effects of social capital, and secondly, on whether they focus on 1) the relations an actor maintains with others, 2) the structure of relations among actors within a collectivity, or 3) both types of linkages (Adler \& Kwon, 2002).

\subsection{The Role of Social Capital in Co-operatives}

As introduced, social capital has been highlighted as important for co-operatives (e.g., Nilsson et al., 2012; Spear, 
2000; Svendsen \& Svendsen, 2000; Valentinov, 2004). Nilsson et al. (2012) argue that as the co-operative is a user-owned and user controlled business that distributes benefits on the basis of use, they are linked to the concept of social capital. In more detail, co-operatives are not about conveying capital gains to investor-owners in proportion to capital invested, but about creating member benefits to associated people in proportion to their patronage in the co-operative - often negotiated after the accounting period in processes that build on the principle of democracy. Thereby, the form of ownership, the distribution of benefits, and the principle of control are all indicative of social relationships between the co-operative and the members and amongst the members (Nilsson et al., 2012).

Further, trust has been regarded as an indicator of social capital (see Nilsson et al., 2012) and also important for the efficient operation of co-operatives (see Svendsen \& Svendsen, 2000). According to Spear (2000), the establishment of any consumer co-operative requires social capital so that the members can efficiently pool their resources together. This idea is supported by the work of Jussila, Goel, and Tuominen (2012), who identify social exchange as important for the formation and success of co-operatives. In addition, co-operatives are similar to social capital in that they are both 'jointly owned' (see Nahapiet \& Ghoshal, 1998; Nilsson, 2001), gaining individual and collective value through networking (Nilsson et al., 2012; Uski et al., 2007; Zurbano, 2005).

Given the above notions, a co-operative can be regarded as a specific form of community-based enterprise (CBE) which can be defined as "community acting corporately as both entrepreneur and enterprise in pursuit of common good" and which is "managed and governed to pursue the economic and social goals of a community in a manner that is meant to yield sustainable individual and group benefits over the short and long term" (Peredo \& Chrisman, 2006, p. 310). Further, in the context of CBEs (like the co-operatives), interaction between the individual and the organization enhances development of a common identity to respond to the challenges and pressures of globalization (Peredo \& Chrisman, 2006).

Social capital of co-operatives represents especially communal nature (see Ibarra et al., 2005) since co-operatives are usually involved with various community development activities, adopt ethical principles and corporate social responsibility (CSR) which benefits the whole community (see Majee \& Hoyt, 2011; Kangayi, Olfert \& Partridge, 2009; Nel, Binns \& Motteu, 2001; Zurbano, 2005; Uski et al., 2007; Jussila et al., 2007; Zeuli et al., 2004; Davis \& Worthington, 1993). Engagement with co-operative values and principles (Dobrohoczki, 2006; Majee \& Hoyt, 2011) steers co-operatives into acting in a socially responsible way. In addition, regionally responsible activities can be seen as a 'must' for organizations that are dependent on particular local stakeholders or stakeholder groups (Jussila et al., 2007). Nevertheless, CSR creates social capital and increases co-operatives' legitimacy in a particular environment, whereas distrust from the community can threaten the survival of the business (Russo \& Tencati, 2009; Loza, 2004).

Valentinov (2004) has also discussed social capital theory of co-operative organizations and argued that a co-operative represents social-capital based organization as it is governed on the basis of co-operative principles much in the same way other organizations are governed through market and/or hierarchy. Spear (2000) explains how the characteristics of co-operatives (e.g., profit distribution constrains, trust dimension derived from the company form, circumstances in which the co-operatives have been established) give them an economic and social advantage compared to other company forms. Further, in social capital-based organizations such as co-operatives, the immediate motive for co-operation is not the individual gain but mediated by mutual self-help objectives where interpersonal relations are critical (Valentinov, 2004). While one could see Valentinov's (2004) view making some distanceto the co-operative principle of economy (Watkins, 1986) and governance through the consumer market (Tuominen, Jussila \& Kojonen, 2009) as well as the role of competence-based authority in the governance of co-operatives (Watkins, 1986), it highlights the importance of social capital for consumer co-operatives and its link to some key principles such as voluntary association and democracy (Novkovic, 2008).

Several other authors (e.g., Igual \& Vidal, 2002; Kangayi et al., 2009; Valentinov, 2004) have also emphasized that co-operatives operate in social economy, emphasizing solidarity, mutual assistance, trust, and social capital. Social capital generates several benefits to co-operatives: better access to information, better communication and coordination, and reduced opportunistic behavior and transaction costs as trust increases (Valentinov, 2004; Svendsen \& Svendsen, 2000). In addition, increased level of social capital has been related to region's economic growth (Svendsen \& Svendsen, 2000).

In sum, although providing some important insights, extant literature is rather fragmented and lacks empirical research on the role of social capital in creating sustained competitive advantage for consumer co-operatives.

\section{Context of the Study}

In more than a hundred years, Finnish retail co-operation has come a long way from small village co-operatives to 
large scale organizations. Currently, S Group has 20 independent regional co-operatives, eight local co-operatives, and the central unit SOK. S Group has expanded to several fields of businesses and currently operates in the grocery, agriculture, consumer goods, service and gas station, travel and accommodation, automotive, and accessories. In addition, S Group has established S Bank (www.s-kanava.fi; accessed $14^{\text {th }}$ of May, 2013).

$\mathrm{S}$ Group is currently the market leader of daily consumer goods in Finland with an exceptionally high $45.2 \%$ market share in 2011 (1.1\% increase from the year 2010). At the end of 2012, S Group had 2.055 million members (at the same time the population of Finland was approximately 5.40 million). Noteworthy, the number of employees in S group has increased rapidly in eight years and, at the end of 2012, S Group employed 43417 people (in 2011, approximately 42,000 employees). Currently, S Group has over 1600 outlets (www.s-kanava.fi, accessed $14^{\text {th }}$ of May, 2013).

In 2012, S Group's retail sales were 12 billion Euros (11.46 billion in 2011) and the group's total profit (for the role of profit in co-operatives, see Hicks, Maddox, Robb \& Webb, 2007) before extraordinary items was 212 million Euros (269 million in 2011). In 2012, members were paid 378.5 million in bonuses (360 million in 2011) and the group's investments to new services and stores were 574 million Euros (546 million in 2011) (www.s-kanava.fi; accessed $14^{\text {th }}$ of May, 2013).

\section{Research Process and Methods}

Our research process began with pilot interviews with experts of S Group co-operatives. We continued the process with 20 tape-recorded qualitative thematic interviews with executives, managers, and supervisory board chairs of $\mathrm{S}$ Group and its co-operatives. Our study represents thematic qualitative case study which is deeply embedded in rich empirical data and aims to build new pieces of theory (Gioia et al., 2012) on the strategic management of consumer co-operatives.

Following the guidelines of thematic analysis (e.g., Braun \& Clarke, 2005; Gioia et al., 2012; Corley \& Gioia, 2004), we studied through the data several times, codified it, analyzed it, and identified implicit and explicit ideas and associations. In the beginning of the data analysis, we first listed all the relevant aspects which emerged from our data that capture something relevant to our research questions (see Braun \& Clarke, 2005) as $1^{\text {st }}$ order concepts. After re-analyzing the data and revising the $1^{\text {st }}$ order concepts, we established 24 different $1^{\text {st }}$ order concepts (see Table 1).

Next, we carried out "axial coding" in which we searched for relationships between categories, which helped to establish $2^{\text {nd }}$ order themes (see Gioia et al., 2012). We analyzed the data several times, re-defined and clarified the specific themes, considering our research questions. Noteworthy, consistently with the work of Gioia et al. (2012), when interviewing the co-operative managers we did not ask directly about the role of social capital in co-operation and co-operative management. Instead, as part of a broader research project, we asked about interviewees' views on co-operation as a form of organization (e.g., ownership, governance, management, structures, special features). It was in the analysis stage that we moved towards our research question first asking ourselves: "are there some aspects related to social capital (e.g., building trustful relationships, community involvement) that are highlighted as important for the co-operatives in our data and if so, what are they and why?"

Understanding the concepts of social capital (see Nahapiet \& Ghoshal, 1998; Putnam, 2000) and consumer co-operation (Tuominen, 2012) were important in order to successfully analyze the data and thus, prior studies in this area also shaped some aspects of the specific themes. However, we tried to go beyond the existing theory taking into account the comment by Gioia et al. (2012) which suggest that "knowing the literature intimately too early puts blinders on and leads to prior hypothesis bias (confirmation bias)" (p. 7). Nevertheless, based on our analysis, we established seven second order themes which were 1) Caretaking and ethics as part of the co-operative model, 2) Strategic CSR, 3) Genuine pursuit of common good, 4) Interacting and sharing a common identity, 5) Development of personal relations, 6) Resources for managing institutional dependencies, and 7) Resources for managing customer-relations. Table 1 summarizes the data structure of our study.

Table 1. Data structure

2nd order themes and the related 1 st order concepts

1. Caretaking and ethics as part of the co-operative model

The co-operative model encourages care-taking on the individual, firm, and environment-levels

Initiative, justice, honesty, openness, solidarity, democracy and equality are part of the co-operative model 


\section{Strategic CSR}

Corporate citizenship (CSR) actions and reporting creates a valuable (good) image for the co-operative amongst partners and stakeholders, including members

All leaders of the local units are educated to be tentative to regional interests and social responsibility

\section{Genuine pursuit of common good}

Co-operative invests in the well-being of the people in its operation area

The co-operative invests in undertakings that have economic and symbolic value in the region

The co-operative genuinely creates surplus that remains circulating within the regional economic system

By favoring regional suppliers the co-operative shows it is genuinely concerned about the value-chain in its operation area

The co-operative focuses on long-term creation of value to its community

\section{Interacting and sharing a common identity}

Customers know the co-operative and can trust in their word having an effect on the operation of their co-operative

The co-operative manifests regional identity and takes care of that identity in its strong influence, which promotes peoples' identification with it and their support for it

Being intimate and sharing identity the customer understand each other

Customer is an owner and, thereby, can view oneself as a partner with the co-operative instead of an object

Due to common identity, people assume the co-operative as their own

\section{Developing personal relationships}

An experienced co-operative $\mathrm{CEO}$ of a regional co-operative is visible, competent, and desired for regional positions of trust

The key representatives of the co-operative have good relationships with the stakeholders

Personal investments of a co-operative CEO in relationships with local decision-makers

\section{Resources for managing institutional dependencies}

Being regional promotes co-operatives' ability to react to demands of the region and impact cities and municipalities opinions

Good personal relations with key stakeholders help in getting business places

Local politicians favor the co-operative that is regional over a company that pays its taxes elsewhere

By being known and trusted by the local decision-makers helps in getting business places

\section{Resources for managing customer-relations}

Being 'local' provides better understanding of customer needs

When people care about regionality and identity, being regional creates a stronger tie

Intimacy between the co-operative and its members lowers mental threshold for feedback

Themes 1-5 represent the aggregate dimension Sources of social capital, while themes 6-7 form the aggregate dimension Strategic benefits of social capital, describing the competitive advantages social capital provides for consumer co-operatives.

\section{Findings of the Thematic Analysis}

Our analysis suggests that the co-operative model encourages care-taking at the individual, firm, and environment-levels, 'caretaking and ethics as part of the co-operative model' being the first out of our seven $2^{\text {nd }}$ order themes. This is consistent with the co-operative principles of association and accountability which direct co-operatives and their members towards being mutually responsible (Watkins, 1986). The data also speaks to particular ethics and values being embedded in the co-operative model, such as justice and solidarity. Such accounts are consistent with co-operative literature (Novkovic, 2008). In other words, care-taking and ethics are part of the co-operative model. Linking this theme to conceptualizations in extant social capital literature, it seems that the co-operative model per se steers towards CSR which can be seen as a source of social capital for consumer co-operatives. In this sense, our analysis aligns with prior co-operative literature of social capital (e.g., Valentinov, 2004). 
Table 2. Caretaking and ethics as part of the co-operative model

1 st order concepts and the selected representative data

The co-operative model encourages care-taking on the individual, firm, and environment-levels

"This company form comes with more comprehensive care of the individual, the company, the operational environment ..."

Initiative, justice, honesty, openness, solidarity, democracy and equality are part of the co-operative model

"The principles of co-operation ... we speak about initiative, justice, honesty, openness, even solidarity ... or democracy, equality ..."

Forming a theme of its own ('strategic CSR'), our analysis also reveals that CSR activities and reporting can be more or less calculated, representing strategic CSR. In other words, consumer co-operatives may actively utilize CSR in their attempts to promote social capital (e.g., through a more positive corporate image). As the co-operatives realize the strategic importance of social capital, they educate all unit leaders to be tentative to regional interests and social responsibility.

\section{Table 3. Strategic CSR}

\footnotetext{
1st order concepts and the selected representative data

Corporate citizenship (CSR) actions and reporting creates a valuable (good) image for the co-operative amongst partners and stakeholders, including members

"When we speak about a corporate citizen or [the co-operative] as a corporate citizen so the objective is that a positive good corporate image is created that is then added value... it comes through actions and, as an example, this corporate social responsibility reporting that is carried out ... it is stakeholder communication above all, that is, for those partners and decision-makers who are the one forum, stakeholders, but probably it is most important to tell to the customer owners ..."

All leaders of the local units are educated to be tentative to regional interests and social responsibility

"We have also strong local leadership, in the level of municipalities and local villages, the managers and superiors of S-markets can be educated to it ... we strongly educate them to regionality and social responsibility ..."
}

Turning to the third theme ('genuine pursuit of common good'), we put forward in our analysis that the co-operative invests in the well-being of the people in its operation area as well as undertakings that have economic and symbolic value in the region. The co-operative creates surplus that circulates within the regional economic system. As a manifestation of their genuine concern for the community and orientation towards long-term creation of value for the community, the co-operatives favor regional suppliers over others. This is consistent with extant literature on how consumer co-operatives approach their communities (Tuominen, 2012; Jussila et al., 2007). Further, placing consumer co-operatives in the social capital discussion, these notions seem to relate to the definition of CBE (Peredo \& Chrisman, 2006). In other words, acting as a CBE, a consumer co-operative is likely to generate, what Ibarra et al. (2005) refer to as communal social capital.

Table 4. Genuine pursuit of common good

1st order concepts and the selected representative data

Co-operative invests in the well-being of the people in its operation area

"How we invest in the well-being of the people of the own region, from it comes exactly this culture issue, investing in youth and upbringing work"

The co-operative invests in undertakings that have economic and symbolic value in the region

"then exactly this development of the economic activity of the own region so that, as an example of this, this story of [an important tourist attraction] can be told... how it has begun to succeed again when the co-operative has become the owner ..."

The co-operative genuinely creates surplus that remains circulating within the regional economic system

"All that money that is created from the operation is left within the region in practice, that is, it goes either as wages or taxes or dividends, as investments it benefits that own operation region ..."

By favoring regional suppliers the co-operative shows it is genuinely concerned about the value-chain in its operation area 
"A co-operative is in fact an enterprise of its region...favors willingly regional purchasing ..."

The co-operative focuses on long-term creation of value to its community

"We ... operate predictably and persistently for the benefit of our own province and for the benefit of the people and we represent this kind of stability and reliability in a positive sense ..."

According to our analysis, when the co-operative and its reactivity are known by the customers, they can trust to be heard and understood. The co-operative also manifests regional identity and takes care of that identity in its strong influence in the region which promotes peoples' identification with it as well as their support for the co-operative. Due to common identity, people assume the co-operative as their own. A factor in interaction and identification is that customers are owners, who thereby may view themselves as partners of the co-operative instead of being an object of business. We interpret that the aspects of this theme 'interacting and sharing a common identity' having elements of cognitive social capital (Cicourel, 1973). Further, interaction and identity sharing are also related to the concept of community-based enterprise (Peredo \& Chrisman, 2006) and, most importantly, provide yet another source of social capital.

Table 5. Interacting and sharing a common identity

1st order concepts and the selected representative data

Customers know the co-operative and can trust in their word having an effect on the operation of their co-operative

"We are known, I'm also known here that it is this kind of an important thing customers can trust in that their words are heard and understood because we can go on the spot to see if something is wrong ..."

The co-operative manifests regional identity and takes care of that identity in its strong influence, which promotes peoples' identification with it and their support for it

"It has been excellent that this kind of an identity essence has been strong in that region and people have been willing to belong to the co-operative, be on its side and so ... have a strong influence in their region and take care of that identity ..."

Being intimate and sharing identity the customer understand each other

"That is again from the point of view of the customer to know the customer, we come to regionality and locality and these identity issues, the visibility over there and so on ..."

Customer is an owner and, thereby, can view oneself as a partner with the co-operative instead of an object

"partnership ... the atmosphere of doing together, that is, this customer is not here as an object but he or she is the owner and customer together ..."

Due to common identity, people assume the co-operative as their own

"Fundamentally it is about regional identity, co-operative identity, locality that is near to people, then it feels like one's own ... "

Moving to the theme five ('developing personal relationships'), key personnel of the co-operative is said to develop good personal relationships with key stakeholders. A co-operative's chief executive officer (CEO) may make significant personal investments in relationships with local decision-makers and, as an experienced, competent, and visible actor, is often desired for regional positions of trust. Such investments in personal relationships can be seen as being associated with Adler and Kwon's (2004) ideas of social capital, Burt's (2007) work on structural holes, and Ibarra et al.'s (2005) notions on both individual and social capital, our interpretation considering the context emphasizing the latter. This theme also evidently links to the creations of relational social capital (Nahapiet \& Ghoshal, 1998).

Table 6. Developing personal relationships

1st order concepts and the selected representative data

An experienced co-operative CEO of a regional co-operative is visible, competent, and desired for regional positions of trust

"I have this long track record (as a CEO) and I can say that in regional level it provides me with visibility and substance to act in different positions of trust to which I am asked all the time.." 


\section{The key representatives of the co-operative have good relationships with the stakeholders}

"our management is there in the region and management and administration have good relationships to, it can be said, all possible stakeholders that affect the operation of the co-operative"

Personal investments of a co-operative CEO in relationships with local decision-makers

"Be involved genuinely in a way that there is a visible person and a decision-maker in the locality and is committed to co-operation ..."

Our analysis suggests that the different forms of social capital discussed above may be used in many ways for the benefit of the co-operative and, thereby, eventually the entire community. The first theme that speaks to this issue is 'resources for managing institutional dependencies'. This theme includes that being regional promotes co-operatives' ability to react to demands of the region and impact cities' and municipalities' opinions. Especially the good personal relations with key stakeholders (actors knowing and trusting each other) help in buying business places proactively. Co-operative management knows what is going on in their business environment and where they should be serving their community in the future. Further, when local institutional actors understand the role of a consumer co-operative as up-holder of and contributor to regional welfare and when fair play rules allow for it (offers for a lot are the same), they tend to favor the regional co-operative over a company that pays its taxes elsewhere. Overall, such notions are consistent with extant consumer co-operative literature (Tuominen, 2012; Uski et al., 2007; Jussila et al., 2007). Moreover, they reflect how co-operatives can use their social capital to improve their competitive position by actively or latently affecting their institutional environment. Noteworthy, in our view the competitive advantage stemming from trust between the co-operative and the regional stakeholders is likely to be rather sustainable, as it is unlikely that an IOF, for example, commits itself to long-term service provision in a given community as they mainly operate in those segments or markets where there are the best possibilities to make high profits. Therefore, achieving that kind of trust related advantage may be more difficult, if not even impossible, for them.

Table 7. Resources for managing institutional dependencies

1st order concepts and the selected representative data

Being regional promotes co-operatives' ability to react to demands of the region and impact cities and municipalities opinions

"Regionality is very important in our strategies...we can be this kind of a regional organization ... we can react in there, also influence regionally as a regional company that operates there, to the direction of cities and municipalities we are much stronger of an opinion-maker than when there could be only some regional manager from Helsinki ..."

Good personal relations with key stakeholders help in getting business places

"through it (good personal relationships with key stakeholders) we succeed, for example, in buying business locations ... this new establishment is easier ..."

Local politicians favor the co-operative that is regional over a company that pays its taxes elsewhere

"If we speak about the issue of the lot in [a street] ... so when we go and negotiate with political decision-makers that some gas station of [the co-operative] is going to be situated there ... and a chain from Helsinki would be coming there at the same time that pays its taxes to Helsinki so there is a certain benefit, if offers [for a business location] are similar they select the provincial [company] ...”

By being known and trusted by the local decision-makers helps in getting business places

"we are known better, it affects positively that it can affect the getting of business locations in the decision-making processes and other things like that ..."

The final theme of our analysis is 'resources for managing customer-relations'. Our analysis suggests, for example, that being relatively local provides better understanding of customer needs. Further, it is seen that when people care about regionality and identity, they will experience a stronger tie with a company that is in fact regional. The intimacy between the co-operative and its members lowers members' mental threshold for feedback. These notions seem to speak to the role of cognitive social capital (Cicourel, 1973) and communal social capital (Ibarra et al., 2005) in providing the co-operative with resources such as customer affective commitment as well as customer participation in developing operations and services, which can be seen as a source of sustained competitive advantage. 
Table 8. Resources for managing customer-relations

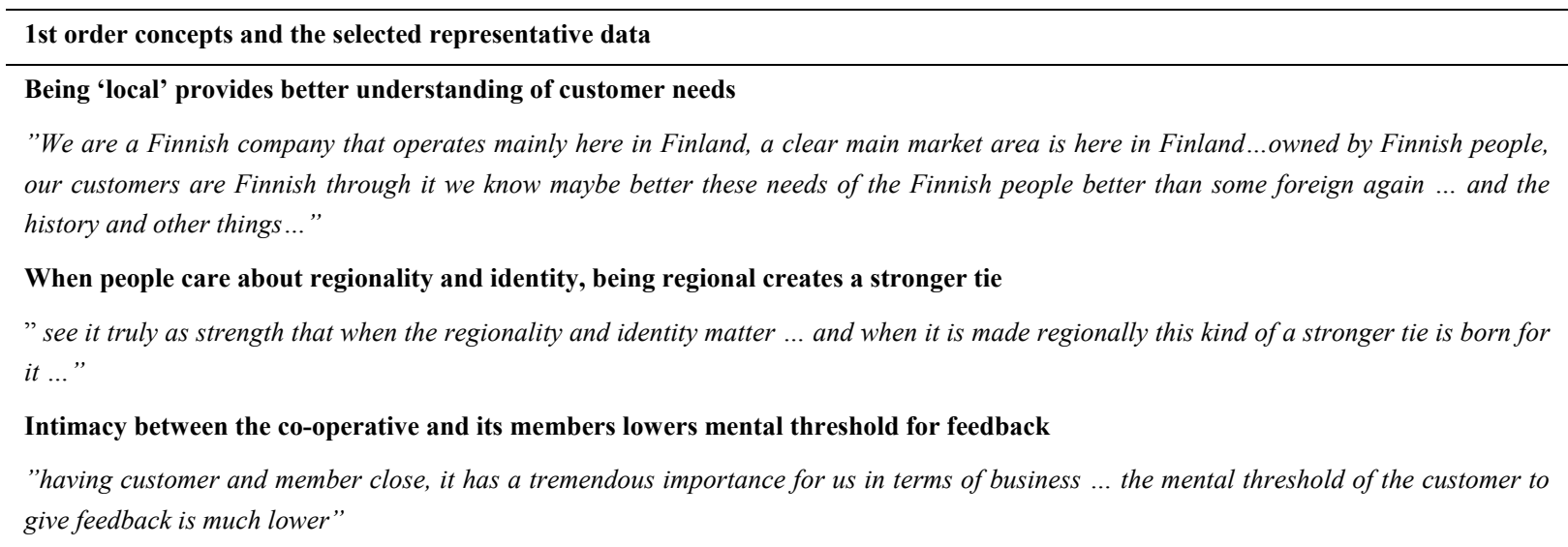

\section{Summary of the Findings}

As introduced, we set ourselves to investigate the development of social capital and the strategic benefits of the utilization of such resources. Figure 2 presents the comprehensive framework concerning the sources of social capital and how the different dimensions of social capital contribute to consumer co-operatives' sustained competitive advantage.

To answer our first research question, we found that consumer co-operatives are able to develop communal social capital because caretaking and ethics are part of the co-operative model. In addition, strategic CSR, genuine pursuit of common good, and interacting and sharing a common identity develop communal social capital. Second, cognitive social capital is developed through interacting and sharing a common identity and through the development of personal relationships. Third, actors of consumer co-operatives (CEO in particular) develop relational social capital by investing into the development of personal relationships.

To answer our second research question, social capital contributes to consumer co-operatives' sustained competitive advantage in that all of the above presented dimensions of social capital in consumer co-operatives (relational, cognitive, communal) create resources for institutional strategies aimed at a better competitive position. In addition, cognitive social capital creates resources for managing customer-relations.

\section{Discussion and Conclusion}

Our study contributes to the studies concerning the competitive advantages of consumer co-operation (e.g., Tuominen et al., 2006; Valentinov, 2004; Spear, 2000; Normark, 1996) in several ways. First, even though close relationships with the community have been highlighted in this field of research (e.g., Jussila et al., 2008; Jussila et al., 2007; Tuominen et al., 2006; Uski et al., 2007; Zeuli \& Radel, 2005; Zeuli et al., 2004; Fulton \& Hammond-Ketilson, 1992), this aspect has not been clearly linked to how various kinds of social capital (communal, relational, and cognitive social capital) are explicitly developed and what kinds of resources the co-operative is able to achieve through the development of social capital.

Second, while extant literature (Tuominen et al., 2006; Fulton \& Hammond-Ketilson, 1992) has suggested that consumer co-operatives have both the knowledge of local conditions as well as the ability to alter those conditions (i.e., to affect and alter local institutions), less attention has been given to the mechanisms involved. Thus, with our findings related to the sources and benefits of social capital we contribute to this discussion by illustrating that the dimensions of social capital (relational, cognitive and communal) create resources needed for implementing institutional strategies in consumer co-operatives.

Third, even though it has been put forward by scholars that co-operative values and principles (Spear, 2000; Valentinov, 2004) create additional trust and social capital, and co-operatives' embeddedness with their communities (and concern for their communities) may provide them with legitimacy in the eyes of local or regional stakeholders (Jussila et al., 2007), research has not so far been able to unpack these issues into a list of the components that are needed in order to achieve those trust-related benefits. Thus, with our findings on the critical aspects of the co-operative model, strategic CSR, pursuit of common good, interacting and identity sharing as well as developing personal relationships, we are able to fill or at least begin filling the knowledge gap. 


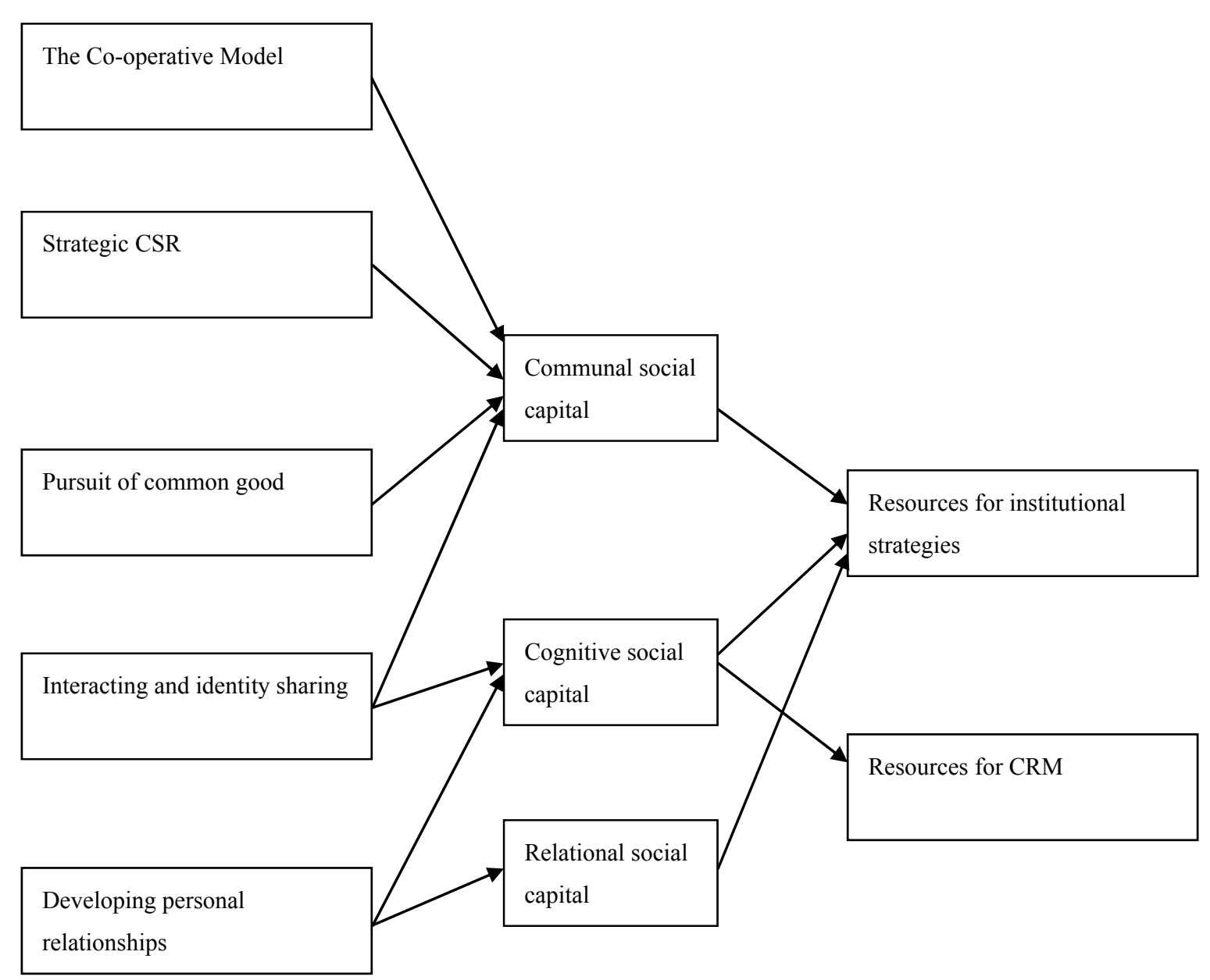

Figure 2. Empirical findings concerning sources and benefits of social capital in consumer co-operatives

As it comes to the value of our study to the practitioners of consumer co-operation as well as wider society, there are some important points to highlight. As many of the sources of social capital are linked to the co-operative purpose and the co-operative model, we think that managers of consumer co-operatives should pay some serious attention to them and utilize their potential in creating a sustained competitive advantage. Sustained advantage stems from social capital since it is not easily imitable for example by IOFs, which mainly seek to operate in the most attractive markets in terms of the profitability available and are not likely to commit themselves to the genuine pursuit of common good (e.g., long-term provision of the services needed by the members of a declining rural community) which is imperative for geographic-bound consumer co-operatives.

In addition, it should be noticed that the question to whom the social capital creates value is important (an employee, farmer, or a customer-owner). For example, S Group has 2.055 million members in Finland whereas the population in Finland is approximately 5.4 million people (www.s-kanava.fi, accessed $14^{\text {th }}$ of May, 2013). Thus, the benefits of S Group social capital are likely to accrue to the wider society (i.e., representing communal social capital) and even enhance the economic development in regions. For example, Svendsen and Svendsen (2000) have suggested that the social capital also has economic impact to the co-operatives' and regions' economic success (even though this can be difficult to measure).

However, there is also another side in the coin. Namely, can consumer co-operatives continue to sustain high levels of social capital while simultaneously struggling with the demands of global competition (e.g., many co-ops aim for economies of scale and are therefore seeking to grow their size and muscles)? For example, will the members still share their identity with the organization they own and view themselves as part of the co-operative instead of an object taken advantage by the organization whose operation their word will not have any effect on? Svendsen and Svendsen (2000) argue that in the case of Danish Dairy co-operative movement, rich pleasant community life collapsed when small, local dairies were shut down. Further, they argue that "any loss in social 
capital must be deducted from the economic gain following economies of scale" (p. 81). However, it should be noticed that Nilsson et al. (2012) and Svendsen and Svendsen (2000) studied producer co-operatives and, therefore, one important stream for future research would be to study the effects the growing size of the consumer co-operatives has on their social capital and what means do consumer co-operatives have to preserve and develop social capital if they grow. Another important starting point to further studies is the trustful relations between the co-operative and the regional stakeholders. That is, what are the boundaries that should not be crossed or are there such boundaries? Should a consumer co-operative get all its investments implemented solely due to the fact that it is a co-operative and seeks to pursue common good? Finally, as we have focused on consumer co-operatives and especially those in retail trade in this paper, we would like to see analyses from other industries, such as banking, where co-operatives have also been common and successful and, where social capital may be even more critical judging by the recent financial crises.

\section{References}

Adler, P. S., \& Kwon, S. W. (2002). Social Capital: Prospects for a New Concept. Academy of Management Review, 27(1), 17-40. http://dx.doi.org/10.5465/AMR.2002.5922314

Barney, J. (1991). Firm resources and sustained competitive advantage. Journal of Management, 17(1), 99-120. http://dx.doi.org/10.1177/014920639101700108

Barton, D. (1989). Principles. In D. Cobia (Ed.), Cooperatives in agriculture. Englewood Cliffs, NJ: Prentice-Hall.

Bourdieu, P. (1986). The forms of capital. In J. G. Richardson (Ed.), Handbook of theory and research for the sociology of education (pp. 241-258). New York, NY: Greenwood Press.

Braun, V., \& Clarke, V. (2005). Using thematic analysis in psychology. Qualitative Research in Psychology, 3, 77-101. http://dx.doi.org/10.1191/1478088706qp063oa

Burt, R. S. (1992). Structural Holes. Cambridge, Mass: Harvard University Press.

Burt, R. S. (1997). The contingent value of social capital. Administrative Science Quarterly, 42, 339-365. http://dx.doi.org/10.2307/2393923

Burt, R. S. (2004). Structural holes and good ideas. American Journal of Sociology, 110(2), $349-399$. http://dx.doi.org/10.1086/421787

Cicourel, A. V. (1973). Cognitive sociology. Harmondworth, England: Penguin Books.

Corley, K. G., \& Gioia, D., A. (2004). Identity ambiguity and change in the wake of a corporate spin-off. Administrative Science Quarterly, 49, 173-208.

Davis, K., \& Burt, S. (2007). Consumer co-operatives and retail internationalization: problems and prospects. International Journal of Retail \& Distribution Management, 35(2), $156-177$. http://dx.doi.org/10.1108/09590550710728101

Davis, P., \& Worthington, S. (1993). Cooperative values: change and continuity in capital accumulation: the case of the British Cooperative Bank. Journal of Business Ethics, 12(11), 849-859. http://dx.doi.org/10.1007/BF00871666

Dobrohoczki, R. (2006). Cooperatives as social policy means for creating social cohesion in communities. Journal of Rural Cooperation, 34, 139-159.

Fulton, M., \& Hammond-Ketilson, L. (1992). The role of cooperatives in communities: examples from Saskatchewan. Journal of Agricultural Cooperation, 7, 15-42.

Gioia, D., Corley, K. G., \& Hamilton, A. (2012). Seeking qualitative rigor in inductive research: notes on the Gioia methodology. Organizational Research Methods, 16(1), $15-31$. http://dx.doi.org/10.1177/1094428112452151

Ibarra, H., Kilduff, M., \& Tsai, W. (2005). Zooming in and out: connecting individuals and collectivities at the frontiers of organizational network research. Organization Science, 16(4), 359-371. http://dx.doi.org/10.1287/orse.1050.0129

Igual, J. F. J., \& Vidal, S. M. (2002). Farm cooperatives and the social economy: the case of Spain. Journal of Rural Cooperation, 30(2), 119-133.

Loza, J. (2004). Business-Community Partnerships: The Case for Community Organization Capacity Building. Journal of Business Ethics, 53, 297-311. http://dx.doi.org/10.1023/B:BUSI.0000039415.90007.56 
Hicks, E., Maddox, J., Robb, A., \& Webb. T. (2007). Co-operative accountability and identity: an examination of reporting practices of Nova Scotia co-operatives. Journal of Co-operative Studies, 40(2), 4-16.

Kangayi, C., Olfert, M. R., \& Partridge, M. (2009). Co-operatives and Rural Community Population Growth: Evidence from Canada. The Review of Regional Studies, 39(1), 49-71.

Jussila, I., Kotonen, U., \& Tuominen, P. (2007). Customer-owned firms and the concept of regional responsibility: qualitative evidence from Finnish co-operatives. Social Responsibility Journal, 3(3), 35-43. http://dx.doi.org/10.1108/17471110710835563

Jussila, I., Goel, S., \& Tuominen, P. (2012). Governance of co-operative organizations: A social exchange perspective. Business and Management Research, 1, 14-25. http://dx.doi.org/10.5430/bmr.v1n2p14

Jussila, I., Tuominen, P., \& Saksa, J. M. (2008). Following a different mission: where and how consumer co-operatives compete? Journal of Co-operative Studies, 41(3), 28-39.

Majee, W., \& Hoyt, A. (2011). Cooperatives and community development: A perspective on the use of cooperatives in development. Journal of Community Practice, 19, 48-61. http://dx.doi.org/10.1080/10705422.2011.550260

Nahapiet, J., \& Ghoshal, S. (1998). Social capital, intellectual capital and the organizational advantage. Academy of Management Review, 23(2), 242-266. http://dx.doi.org/10.2307/259373

Nel, E., Binns, T., \& Motteu, N. (2001). Community-based development, non-governmental organizations and social capital in post-apartheid South Africa. Geografiska Annaler, Series B: Human Geography, 83, 3-13. http://dx.doi.org/10.1111/1468-0467.00086

Nelson, R. (1989). The strength of strong ties: Social networks and intergroup conflict in organizations. Academy of Management Journal, 32, 377-401. http://dx.doi.org/10.2307/256367

Nilsson, J. (2001). Organisational principles for co-operative firms. Scandinavian Journal of Management, 17, 329-356. http://dx.doi.org/10.1016/S0956-5221(01)00010-0

Nilsson, J., Svendsen, G. L. H., \& Svendsen, G. T. (2012). Are large and complex agricultural cooperatives losing their social capital? Agribusiness, 28(2), 187-204. http://dx.doi.org/10.1002/agr.21285

Normark, P. (1996). A role of cooperatives in the market economy? Annals of Public and Cooperative Economics, 67(3), 429-439. http://dx.doi.org/10.1111/j.1467-8292.1996.tb01914.x

Novkovic, S. (2008). Defining the co-operative difference. The Journal of Socio-Economics, 37, 2168-2177. http://dx.doi.org/10.1016/j.socec.2008.02.009

Peredo, A., M., \& Chrisman, J. J. (2006). Toward a theory of community-based enterprise. Academy of Management Review, 31(2), 309-328. http://dx.doi.org/10.5465/AMR.2006.20208683

Pfeffer, J., \& Salancik, G. R. (1978). The external control of organizations: a resource dependence perspective. New York, NY: Harper \& Row.

Putnam, R. D. (1993). Making democracy work: civic traditions in modern Italy. Princeton, NJ: Princeton University Press.

Putnam, R. D. (2000). Bowling alone: The collapse and revival of American community. New York, NY: Simon \& Schuster.

Russo, A., \& Tencati, A. (2009). Formal vs. informal CSR strategies: Evidence from Italian micro, small, medium-sized, and large firms'. Journal of Business Ethics, 85, 339-353. http://dx.doi.org/10.1007/s10551-008-9736-x

Spear, R. (2000). The co-operative advantage. Annals of Public and Cooperative Economics, 71(4), 507-523. http://dx.doi.org/10.1111/1467-8292.00151

Svendsen, G. L. H., \& Svendsen, G. T. (2000). Measuring social capital: The Danish co-operative dairy movement. Sociologia Ruralis, 40(1), 72-86. http://dx.doi.org/10.1111/1467-9523.00132

Tuominen, P. (2012). The purpose of consumer co-operation: Implications for the management and governance of co-operatives. Acta Universitatis Lappeenrantaensis, 487.

Tuominen, P., Jussila, I., \& Saksa, J. M. (2006). Locality and regionality in management of Finnish customer owned co-operatives. International Journal of Co-operative Management, 3(1), 9-19.

Tuominen, P., Jussila, I., \& Kojonen, S. (2009). Overcoming challenges to governance of consumer co-operation: 
analysing reports of key representatives. International Journal of Co-operative Management, 4(2), 22-35.

Uski, T., Jussila, I., \& Saksa, J. M. (2007). Regional retail co-operation: A strategic network perspective on a customer-owned organization. Journal of Co-operative Studies, 40(1), 18-29.

Valentinov, V. (2004). Towards a social capital theory of co-operative organisation. Journal of Co-operative Studies, 37(3), 5-20.

Zeuli, K., \& Radel, J. (2005). Cooperatives as community development strategy: Linking theory and practice. The Journal of Regional Analysis \& Policy, 35(1), 43-54.

Zeuli, K., Freshwater, D., \& Markley, D. (2004). Cooperatives in rural community development: A new framework for analysis. Journal of the Community Development Society, 35(2), 17-35. http://dx.doi.org/10.1080/15575330409490130

Zurbano, M. (2005). Services, networks and territory: The case of MCC in the Basque Country. The Service Industries Journal, 25(4), 547-561. http://dx.doi.org/10.1080/02642060500092352

Watkins, W. P. (1986). Cooperative principles. Today and tomorrow. Manchester, UK: Holyoake Books.

Woolcock, M., \& Narayan, D. (2000). Social capital: Implications for development theory, research, and policy. World Bank Research Observer, 15(2), 225-250. http://dx.doi.org/10.1093/wbro/15.2.225

\section{Copyrights}

Copyright for this article is retained by the author(s), with first publication rights granted to the journal.

This is an open-access article distributed under the terms and conditions of the Creative Commons Attribution license (http://creativecommons.org/licenses/by/3.0/). 